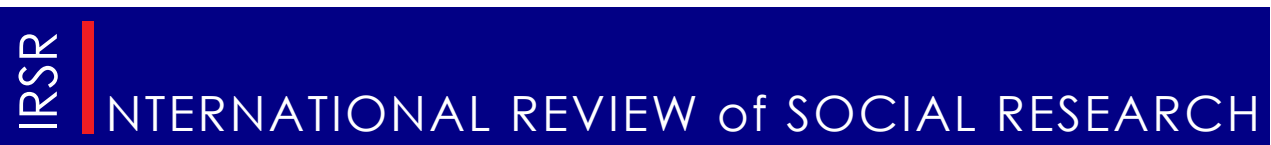

\title{
A Place Called Supermarket
}

\author{
Maria Elisabeth GOIDANICH \\ Federal University of Santa Catarina (UFSC)
}

Carmen RIAL

Federal University of Santa Catarina

\begin{abstract}
The objective of this study is to interpret supermarket stores as privileged spaces for the observation of social relations. The article is based on an ethnography of shopping conducted in the city of Florianópolis, Brazil, by observing middle class housewives during their daily shopping in supermarkets. These stores are seen as places, in opposition to that proposed by Augè (1995), who affirms that supermarkets are non-places produced by supermodernity. The article discusses the history of supermarkets, their role in the cultural and social transformations of the twentieth century, as well as ethnographic data, and shows that it is possible to identify many social interactions inside Brazilian supermarkets.
\end{abstract}

Keywords: supermarket, place, daily practices, sociability.

One ethnographic moment: the Angeloni ${ }^{1}$ store on Beira-Mar Avenue in the city of Florianópolis ${ }^{2}$, around seven o'clock in the evening. A time of day when people finish work and pass through crowded supermarkets to buy some groceries or do their weekly or monthly shopping. A woman hurriedly pushes her cart through the fruit and vegetable aisle, not paying attention to other shoppers around her. She heads to the wine section, slows down and searches among the many bottles of different brands, prices and nationalities for one that suits her interests. Her gaze, lost among

-email: bethgoida@gmail.com. Maria Elisabeth Goidanich is Doctoral student in the Post-Graduate Program in Human Sciences (PPGICH) at the Federal University, Santa Catarina (UFSC). Carmen Rial is Anthropology Professor at the Federal University, Santa Catarina. 
the shelves, reminds me of scenes in a Brazilian film called '1,99 - um supermercado que vende palavras', [1,99 a supermarket that sells words] directed by Marcelo Maragão (2003). In silence, and on a white background, the film shows people walking around, apparently hypnotized, in search of concepts, slogans printed on white packages of varying sizes and formats. The film is a critical reflection on consumerism and the consequent individualism that characterizes contemporary modern societies.

Supermarkets, like boarding homes and bank machines, would be, as Augé (1995) suggests, nonplaces produced by supermodernity, which is characterized by excess, an overabundance of time, space and egos. The author defines non-places by contrasting them to the sociological concept of places, i.e. cultures located in time and space. Places are identitarian, relational and historic. Non-places, would thus be spaces without histories or repertoires that belong to 'a world thus surrendered to solitary individuality, to the fleeting, the temporary' (1995: 78). In non-places, interpersonal communication does not occur and, if it does, it is insignificant. The forms of communication found in these spaces include visual and audio resources such as posters, signs, signals, symbols, and public speakers. Non-places do not have spaces for socialization, cultural exchange and identification. It is exactly this idea that will be questioned.

Another ethnographic moment: the Angeloni store on Avenida BeiraMar, on the same day and time. In the fruit and vegetable aisle, the hurried woman passes by three people, a couple and a man apparently talking about a company for which both men have worked. The man who is not part of the couple is not alone, he stands next to a shopping cart, where there is a baby sleeping on a baby seat. His wife is selecting fruit while he talks to his acquaintance. Back in the wine section, the hurried woman passes two men standing in the middle of the corridor. They seem to be excitedly scheduling a friends gathering and suddenly each goes in a different direction. In front of them, the hurried woman gives a disapproving look to a group of store employees who are also excitedly talking. In another aisle, samples of a Brazilian coffee brand called Três Corações are being offered. I approach the stand where two women are talking, the young promoter and an elderly shopper. I ask for a coffee while they discuss eye color. The promoter is wearing blue contact lenses. The elderly shopper looks into my eyes and immediately includes me in the conversation, saying that I do not have to wear contact lenses for my eyes to turn blue. For a few moments we exchange impressions about eye color, he influence of clothes and the color of the sky in the tonality of the eyes. I say good-bye to my two interlocutors and sit on a bench near the checkout counters to observe. I am not alone for long. Soon, an 86 year-old man sits by my side and starts a conversation. $\mathrm{He}$ asks me to guess his age, tells me details about his life, wants me to guess his profession and shows me his retired deputy identification. When I say good-bye, Mr. Fagundes ${ }^{3}$ protests: 'it's still early!' He's flirting with me!

If the first situation allows one to perceive supermarkets as non-places, 
the second departs from that idea, allowing the perception of supermarkets as places where communication and socialization occur. Even the hurried woman looking for a bottle of wine was probably preparing for an encounter with one or more people and, although apparently alone, she was actually carried expectations about this encounter.

The same space, then, may be considered both, a place and a nonplace. Augé affirms that non-places never exist in a pure manner, as indicated by the interactions found inside supermarket stores. One may also consider the possibility of the alternation of conditions, according to the uses made of the space (De Certeau, 1998). The second perspective of the same scene, described earlier, is more focused on the individuals, shoppers in supermarket spaces, which allows the perception of the space as a place.

Therefore, this text approaches supermarkets as historical and relational places that may be considered a new sociological place, produced by supermodernity, late modernity or hypermodernity ${ }^{4}$. By observing, analyzing and interpreting relations that occur in this space - the supermarkets interpreted as a scenario for interaction (Goffman, 1959) - while middle class women from Florianópolis do their home shopping, that I am able to identify it as a place.

This work is based on an ethnographic study of supermarket shopping practices conducted from July 2008 to October 2010, in Florianópolis in Southern Brazil. During this period, I interviewed and followed 20 middle class women during their supermarket shopping. I also went to the stores many times to observe the movement of people and products and on some of these occasions, I also went shopping, since I was already in the store.

In order to conduct an ethnographic study of shopping, it is necessary to distance oneself from the familiar (Velho, 1980; Fonseca, 1999), since I am also a purchaser of home supplies. Therefore what may be a complicating factor, may also facilitate the process, because every time I need something for my house, I visit the field with my attention focused on collecting data, even during my own shopping practices.

Supermarket shopping practices are quite complex and involve more than objective decisions about brands and products. I consider them to be practices for other practices. According to Warde (2005), what characterizes a practice is that it consists in a nexus between actions and discourses, that are related to one's understanding of what must be done: by procedures - rules, principles, precepts and instructions; and by engagements objectives, projects, tasks, beliefs, emotions and moods. Supermarket shopping practices also consist of performances, which means that the agent is also a carrier of a corporal behavior standard and of certain routine forms of desire, knowledge and understanding. Warde considers consumption a process, in which agents are engaged in the appropriation of goods, services, performances, information or ambiance - a place. Consumption, therefore, is not a practice, but a moment in nearly all practices. Therefore, the act of going shopping and the agents' performances inside supermarket stores while 
consuming may be considered social practices, considering that they obey understandings, procedures and engagements, require knowledge and, in general, follow routines and are part of daily life. To acquire products needed at home through shopping, therefore, is a practice related to other practices that maintain domestic life. The choices shoppers make inside supermarkets tell a lot about the values that guide the administration of private life in each domestic habit, such as cleaning, personal hygiene, as well as eating, education, the socialization of children the family and the relations among couple's, and class relations (housewives and maids, shoppers and store employees). In this sense, supermarkets are places where social and individual orders are constructed through shopping practices.

In this study, women are understood as shoppers. The fact that they are consumers is not denied, however, it is from their practices as shoppers, individuals in stores to purchase goods that will be consumed by themselves and others, that I build my argument. From this perspective, supermarkets may be seen as places, contrary to Augé's affirmation.

\section{Supermarkets, places of passage, places of anonymity}

Non-places are characterized as places of passage, which corresponds with what has been observed in the field. Planning supermarket visits with women participating in this study, for example, was not an easy task, because the visits require scheduling these. When trying to arrange a visit,
I would often hear from the women that they had already gone to the supermarket, because they 'happened to pass nearby', as they would say. This has implications both on the field observations, since it has only been possible to observe previously planned visits, and, also in the women's own shopping practices, which brings attention to the factor of time and how it is organized in daily practices. Another interesting factor raised by the observation of supermarkets as places of passage is how supermarket visits intersect and compete with other daily activities for time as a consumable resource (Shove, 1996). Supermarkets, in this way, are also places of passage, especially in their relation with one's organization of time and, as such, these spaces propitiate anonymity, as Augé (1995) and Pétonnet (1987) propose. Rochefort (2007) also affirms that supermarket purchases are anonymous, that is they allow one to be free of any moral judgement when selecting a product. According to Pétonnet, this is one of the main reasons for the success of supermarkets, since anonymity assures the non-exposure of the most intimate desires. For Pétonnet, anonymity is a state, while socialization is an attitude. Therefore, anonymity does not impede socialization, it allows the individual to use a protective film to protect one's intimacy, keeping the individual safe from embarrassment and danger. At supermarkets, then, options are available and shoppers may be disposed or not to socialize, even if they are anonymous most of the time. 


\section{Supermarkets, places with histories}

As a modern invention, supermarkets or self-service stores first appeared at the beginning of the twentieth century in the United States and, at the time, were considered a revolution in commercial relations, which had been characterized by the presence of the salesperson from whom the shopper had to request a product, overtly announcing desires, especially to the vendor and to the other customers present at the store. In addition, time was controlled by the vendor, who would attend one client at a time, making the others wait their turn. Vendors also had more influence in a shoppers' choices. Since products were bought in bulk and were kept in containers or shelves, the trust in the information provided by vendors defined choices made by clients. ${ }^{5}$

Self-service stores arose along with other technological transformations of modernity that altered relations with space and time. Stores became larger so that products could be exposed to shoppers. As a result, time began to be controlled by shoppers and purchasing processes seemed to be faster. Changes in packaging are also part of this history. At first, products were weighed and packaged in the presence of the buyer, but they began to arrive at the store weighed and packaged from, which also led to important changes in production processes. The importance of packaging in building shopper's trust and desires sparked a revolution in the graphic arts and the communication industry, especially in design and advertising. Supermarkets increasingly determined which brands and products were offered, characterizing a transfer of power from the manufacturing to the retail sector (Miller, 1995; Osterveer, Guivant and Spargaaren, 2007).

This history of the major changes engendered by the emergence of selfservice stores perhaps reinforces the idea that supermarkets are non-places produced by supermodernity. It is thus necessary to observe more closely the stores themselves, which have names and brands that identify them. This allows perceiving that supermarket chains also have their own histories. The Brazilian Angeloni supermarket chain is an example. Angeloni has 22 stores in Santa Catarina and Paraná States in Southern Brazil. It began as a small grocery store specialized in ham in 1958 in the city of Criciúma, Santa Catarina. At the time, it was run by the brothers Antenor and Arnaldo Angeloni ${ }^{6}$. Being a family-owned chain from Santa Catarina, may allow it to establish a closer relationship with customers than another brand present in Florianópolis called Big, which is owned by Walmart, a transnational distribution company. 'The girls say: mom, you only go to Angeloni. But I like Angeloni', Vivian, a 50-year-old housewife, told me, without knowing how to explain why she likes this brand. A few moments later, she said that Angeloni's store in the Santa Monica neighborhood makes her comfortable, because she knows the store and the butcher, 'Seu Zé' (Mr. Zé). This attitude towards a specific store also allows seeing with greater relativity the idea of supermarkets as places of anonymity.

Women's perceptions and experiences while shopping in a specific store can also mark their stories. The woman I accompanied, for example, point to significant differences between 
the Angeloni stores and Big, which is located in the Iguatemi Shopping Mall and, as the name suggests, is the preferred choice of the women when purchasing a more items. For daily purchases, in other words, when they need to buy just a few items, the women I spoke with usually go to smaller stores, like Angeloni's store in Santa Monica, or, even to minimarkets closer to their homes. Their experiences indicate that Big is a good place to buy cleaning and hygiene products andnonperishable food, 'it is cheaper', but shopping there requires close attention when selecting items, because they say the prices advertised in this store often do not correspond to what is charged.

Angeloni has two stores in the region, one on Beira-Mar Avenue and one in the Santa Monica neighborhood (in front of the Iguatemi Shopping Mall). Angeloni Santa Monica is chosen by the participant women because it is smaller, while Angeloni Beira-Mar is rejected by some, for being too big. Marinka's opinion about Angeloni Beira-Mar is interesting: 'Angeloni Santa Monica is too serious, I prefer the Beira-Mar store, it is more fun.' The three stores, Angeloni Santa Monica, Angeloni Beira-Mar and Big are close to one another and receive a large portion of the clientele in the region, including people from beyond their neighborhoods. Angeloni Santa Monica and Big are very close neighbors, about sixty meters from each other, as can be seen on the map. Sometimes shoppers go to the two stores on the same day to get better deals or to purchase products that are only available in one of the stores. At Big, they buy cleaning products and non-perishable food, and then they go to Angeloni to buy fruits, vegetables, meat and cheese, such as Aviação cottage cheese, a product only available in Angeloni stores.

The layout, or the spatial distribution of furniture, products and services in supermarkets is planned to establish a specific relation with shoppers according to their purpose: to stimulate sales (Rennó, 2006). According to Augé (1995), this is a characteristic of non-places, considering that supermarket stores have a purpose and the relations between individuals and these spaces are based on this purpose. Supermarket associations ${ }^{7}$, the trade journals ${ }^{8}$ and market research institutes, invest great effort in studying trends in shoppers' behavior. It has been observed, for example, that it is important to place on the same aisle, a food product and the equipment needed for its preparation". The opportunities for commercial exploration of these spaces are constantly being researched and transformed.

However, for the women I followed, knowing where products are in a store is an important factor when choosing where to shop. Supermarkets, as non-places that only exist for the purpose of selling products, feature distinct characteristics and conquer clients' preferences according to the spatial relations they offer. They thus become places with territories marked in shoppers' minds, allowing each shopper to appropriate and identify with the stores where she usually shops. Therefore, changes in the location of products in a store generate irritation and confusion among shoppers. The routes shoppers take inside supermarkets do not seem to be those planned by the stores and 
vary according to what the shoppers are looking for, and a desire to check prices and promotions, which does not necessarily mean that the products checked will be purchased.

None of the shoppers that participated in this research went through all the aisles. They pass by the aisle entrances, look down them and only enter if they: see something that previously planned to purchase; perceive a need that was not on the list and is on that aisle; or see products or other stimuli, such as a sale that interest them. Even if they go from one side of a store to the other, there is always a moment when they go back to an aisle that had already visited. What seems to have happened, in addition to perhaps having forgotten an item, is that they take a mental register of a product that they may purchased, items that are desired but judged not necessary, and return later to make up their mind Vicky, for example, who decided to go on a diet, passed by the chocolate bars she likes and decided not to take them. Later, she passed by that aisle again and said: 'Maybe I should take it for Marcos' (her 10-year-old son), but decided not to. Finally, she passed by a third time and picked up three chocolate bars. Jane, saw a pan when she arrived at a store and after picking everything that was on the list, went back to where the pan was, opened the package, evaluated the product, compared it with others and, finally, decided not to purchase the item.

If, as Augé says, people go to supermarkets only to shop, how can it be explained that, at stores in Florianópolis and others that I have visited in Brazil, there are, in addition to the aisles, shelves, bakery and butcher, spaces for socialization, where customers can have a break from shopping, even if after this break they may continue to consume? The medium and large stores in Florianópolis offer, both outside and inside, food courts where customers are able to sit and talk or, even, as I saw once, read a book. Large stores offer food courts with a variety of restaurants. Every time I had been to Angeloni Santa Monica with Vicky, for example, we had coffee at the food court located inside the store. We sometimes arranged to meet there, other times we just sat there to talk and wait for her husband or her mother after we had finished shopping. The food court at Angeloni Santa Monica is a meeting place not only for shoppers, but also for people who work nearby. Men wearing suits discuss business, young students hang out there and, occasionally, lively conversations among attendants are seen.

Every morning, at Angeloni Santa Monica, breakfast is served for customers, free of charge. The store offers a variety of teas, cakes and cookies prepared in its bakery. Angeloni Beira-Mar, has a central counter that offers coffee to shoppers. In these spaces, people get together maker and usually chat, showing a clear sign of cordiality. There is no loneliness as Augè proposes. What has been observed is that physical spaces at the stores visited are arranged for shopping and for socializing.

Other store areas reproduce, or present themselves as, spaces for interaction between vendors and clients in the 'old fashioned' way. These spaces include the butcher, the fishmonger and the bakery, where shoppers must take a number and wait 
their turn to be served. In these spaces, shoppers ask attendants for advice even though they are not experts in the products they are selling. Attendants are expected to fulfill their social role. According to Goffman (1959) shoppers expect compatibility and coherence between environment, appearance and manner. An episode with Karen, a 46-year-old music teacher, at Big, is an example of these interactive processes. She wanted to buy salmon, so she checked the prices of frozen salmon and decided to examine the fresh fish on display. She asked for help and the attendant answered Karen's questions with apparent knowledge. The conversation lasted a relatively long time until, based on the man's advice, Karen bought a whole fresh salmon. I already knew him, he had been my student, and I noticed he was being very creative in his answers. He told Karen that salmons are bear food in the Chilean mountains. I knew that the salmon sold in Florianópolis' supermarkets are produced in fish farms. I also knew that there are no bears in Chile ${ }^{10}$.

\section{Supermarkets, relational spaces or spaces for interaction}

This text has reported on several interactions inside supermarkets. I noticed that the relation of the women with Angeloni, for example, is based on: affection, 'I like Angeloni'; perception, 'Angeloni Santa Monica is too serious, I prefer Angeloni Beira-Mar, it's more fun'; and sensation, 'Angeloni Santa Monica is comfortable'. The women appropriate the supermarket space, transforming it into a place to which meanings are attributed. Regarding interpersonal relations, I highlighted the fact that the physical spaces of the stores provide spaces for socialization, such as food courts. Conversations also occur in other parts of the stores, such as the aisles, among groups of employees, groups of customers or employees and customers.

Based on my observations, I believe that it is possible to define interactions inside supermarket stores as direct or virtual. I define as direct those occurring inside the stores, when people exchange information with other people physically present in the same space, whether shoppers or employees. In this way, another shopper looking for the same product may become a competitor, since this individual occupies the space between the first shopper and the product. Or the shoppers may become allies in the search for the product desired. Similar needs establish identifications. Karen was looking for low-lactose milk for her son who is lactose intolerant. She said aloud what she was looking for. Another shopper who was nearby interrupted our conversation and said that the product was in another aisle. An exchange of information began on the subject and each woman reported her experience with the problem of lactose intolerance, difficulties in feeding their young children who have the same problem, how it was discovered in each child, and so on.

Not all direct interactions are positive. Sometimes the presence of others in a store causes discomfort. Examples of this situation are when trolleys are left behind in the middle of an aisle or when customers demand an attendant's attention for a long period 
of time. The situations of greatest discomfort, however, are generally related to employees, either because they give incorrect information or interfere in conversations when not asked to. Once I was with Vivian in the fruit and vegetable aisle at Angeloni Santa Monica talking about the fruit that she was selecting. She was showing me how to select good apples when someone who works in that section interrupted the conversation. Vivian's discomfort was evident. The same happened when Vicky was looking for crystal sugar. While commenting that she could not find this product, a young employee approached and said that the product was not available at the moment. Vicky thanked the boy and her facial expression betrayed her. Store employees, on occasions like these, may be considered what Goffman (1959) defines as non-persons, that is, they are part of the scene but treated as if they were not there. Jane also expressed her discomfort in having too many employees in her way when a man wearing a supermarket uniform passed by us evidently upset, probably because he was having a problem at work. He was saying 'I don't need to go through this' and Jane, a 42-yearold housewife, commented: 'this is the problem about coming early to the supermarket, we have to hear these things.' As Goffman says, 'urban life becomes unbearably uncomfortable for some if all the contacts between two individuals entail participation in afflictions, troubles, and personal secrets', especially when these contacts come from those who are considered non-persons in the scene. This configures a class hierarchy in the perception of shoppers'.
Virtual interactions, on the other hand, are mediated by products that are observed and selected or not. Therefore, each product relates to a part of domestic, family and social life. Glasses displayed on a supermarket shelf made Jane remember the last party that she had at her house, when many glasses were broken, 'but it was a good party', she concluded. Upon seeing a juice package, Vivian remembered her daughter's graduation coming up the following week and that she was going to receive guests at her house, so she was concerned about breakfast for the guests. There are no products on the supermarket shelves that don't elicit a story or inspire a comment. For Douglas and Isherwood (1979), the consumption of goods gives meaning to social life, and goods serve as accessories for rituals, as a form of communicating something about the individual or the family. This may help one to understand the stories related to the products offered on supermarket shelves, but does not seem to be a sufficient explanation. It is not only to have meanings that products are chosen and used by someone. Products also have other roles as expressions of the shoppers' materialized relations with those whom they love and with their own duties as mothers and housewives.

Miller (1998) affirms that the theme of everyday shopping acts is devotional love, which means that shopping is directed toward others, like children, companions, the home, etc. The act of shopping is the interpretation of the other as a desiring subject (Miller, 1998). Desires are not always satisfied when shoppers make decisions concerning other's needs. 
Passing in front of the condensed milk cans, Karen remembered her eldest son: 'Peter loves condensed milk', she said, but did not take the product, considering that it is not healthy for him. It is clear that these women shop based on a necessity of recognition by their families. Devotional love, according to Miller, is not unconditional, it requires retribution and recognition. Vicky, for example, when choosing a can of tomatoes, proudly told me about a spaghetti sauce recipe that she usually prepares and that 'everyone at home loves'. Another concern present in the shopping practices of all the participant women is the socialization of the family, especially children. This is present in the act of buying special snacks and beverages for children's friends, whether it is beer for grownup children or popcorn and pao de queijo (cheese breads) for younger ones, for children, or to take to other places, like popcorn to watch a movie at a friend's house or food for collective snacks at school. Shopping, therefore, is related to social appearance.

One type of interaction that occurs in supermarkets is quite concrete, but also virtual: the use of cell phones. I often observed cell phone conversations about shopping practices while the women were shopping. A son or a daughter who calls his or her mother while she is shopping to remind her to buy a desired item. A daughter who calls her mother from the supermarket to make sure she is picking the right brand. I once met by chance the husband of one of the shoppers who I used to follow. He was on the phone asking for instructions about the brand of cheese he wanted to buy. On the shopping list his wife had prepared, this item was not specified, so he said: 'You know how it is Jane? If I take the wrong brand, I'll hear about it all week'. Therefore, supermarkets are places where direct and virtual interactions occur. There is no loneliness inside supermarket stores, even if an unaccompanied shopper is there for a meeting with herself or with others, whether the others are present with this person in the store, over the phone or simply in her emotional memory.

\section{Final considerations}

Throughout this text I have given reasons to indicate that supermarkets can be recognized as places. I based my arguments on an ethnographic study of shopping practices for domestic purposes in supermarkets, conducted through participant observation, by following middle class women from Florianópolis during their shopping practices. Elements that would characterize self-service stores as non-places according to Augé (1995) have been deconstructed by the identification of the various uses of space, and of how the spaces, relations and interactions that occur in the stores are constituted.

Like non-places, supermarket stores are characterized as spaces of passage that propitiate anonymity. This anonymity in supermarkets, however, does not prevent interaction and sociability. Considering concepts proposed by Pétonnet (1987), it has been affirmed that women shoppers in supermarkets may maintain a state of anonymity most of the time they are in the stores, especially because this creates a protective film, but they may 
also have moments when they are open to socialization.

To consider Augé's affirmation that non-places are unhistorical, I briefly presented the history of supermarkets and of a particular chain of stores involved in this study. I also commented on the distinctions that shoppers make between different supermarkets. I have tried to make the point that each supermarket chain or specific store has distinct characteristics that influence shoppers' choices, and how these characteristics are, in a certain way, connected to subjective issues involved in identification.

While discussing the relations that take place inside the physical spaces of the supermarkets, I have tried to show that, while planned to sell products, supermarkets also offer spaces for interaction and socialization. These spaces are either planned, like restaurants, snack bars and coffee stands; or informal, like the aisles. What seems clear is that supermarkets may be identified as territories that have particular maps and populations, formed by shoppers and employees who are in interaction. Each one in his or her own manner, shopper or employee, appropriates the space, and resignifies it.

This interaction, I propose, occurs directly, in the presence of people in the supermarket, or virtually, through interactions mediated by products on display that are involved with shoppers' relations with other people like children, husbands and friends (Miller, 1998). Direct interaction may be positive or negative and, many times, the interference of employees in shoppers' conversations and choices may be seen by shoppers as intrusive. Therefore, employees, may be considered nonpersons, individuals who are necessary but should not appear on the scene, as Goffman (1959) says.

The observation of the materiality of products on the shelves, trolleys and other physical spaces of supermarkets, as well as the presence, choices, expectations, satisfactions and dissatisfactions of shoppers in stores allows considering the dialectical relationships between subject-object and individual-society, as proposed by Miller (1987). Far from being non-places in which individuals are destined to being alone, supermarkets are super-populated by relations and meanings.

\section{Notes}

${ }^{1}$ Angeloni is a chain of supermarkets and related retail stores. It has supermarkets and supercenters, (which combine various services in one place, such as restaurants, drugstores and locksmiths. It is present in many cities in Santa Catarina State and in city of Curitiba, in Paraná. It has six stores in the Florianópolis' metropolitan region. (http://www.angeloni.com.br/lojas/index)

2 Florianópolis is the capital of Santa Catarina State in southern Brazil.

${ }^{3}$ All the names cited in this study have been changed to assure the interlocutors' privacy.

${ }^{4}$ According to Augè (1992), Giddens (1990, 1991), Bauman (1994), Lipovetsky (2006) and other authors.

${ }^{5}$ Even today, in some specialized stores, this is how commercial relations with individuals work. Specialized stores are understood as those that concentrate their activities on the commercialization of certain categories or types of products. 
${ }^{6}$ http://www.angeloni.com.br/ grupoangeloni/historia.

7 ABRAS - Associação Brasileira de Supermercados (Brazilian Supermarket Association), ACATS - Associação Catarinense de Supermercados (Supermarket Association of Santa Catarina), among others.

8 Supermercado Moderno (ABRAS), Modern Supermarket magazine, among others.

9 In the coffee aisle, for example, paper filters, thermos bottles and other products used to prepare coffee are sold.

${ }^{10}$ It is interesting to observe that the man who was attending had been my student and was not an experienced fishmonger. His statements in his conversation with Karen about the capture, transportation and handling of fish were based on his training and some creativity. He embellished a bit to make a more dramatic presentation, as discussed by Goffman (1959).

\section{References}

Augè, M. (1995) Non-Places: Introduction to an Anthropology of Supermodernity. London, New York: Verso.

Bauman, Z. (1994) Modernity and Ambivalence, Cambridge: Polity.

De Certeau, Michel. (1998) The Practice of Everyday Life. Bekerley, Los Angeles, London: University of California Press.

Douglas, M. and B. Isherwood (1979) The world of Goods: Towards an Anthropology of Consumption. Middlesex: Penguin.

Fonseca, C. (1999) 'Quando cada caso não é um caso. Pesquisa etnográfica e educação’. Revista Brasileira de Educação, 10 (1): 58-78.

Giddens, A. (1990) The Consequences of Modernity. Cambridge: Polity.

Giddens, A. (1991) Modernity and Self-Identity. Self and Society in the Late

Modern Age. Cambridge: Polity.

Goffman, E. (1959) The Presentation of Self in Everyday Life. New York:

Doubleday.

Lipovetsky, G. (2006) Le Bonheur Paradoxal. Essai sur la Société d'

Hyperconsommation. Paris: Éditions Gallimard.

Miller, D. (1987) Material Culture and Mass Consumption. Oxford: Basil

Blackwell.

Miller, D. (1995) 'Consumption as the vanguard of history'. In Miller, D. (ed.) Acknowleging Consumption: A Review of New Studies, pp. 1-15. London and New York: Routledge.

Miller, D. (1998) A Theory of Shopping. New York: Cornell University Press. Osterveer, P., J. Guivant and G. Spargaaren (2007). 'Shoping for green food in globalizing supermarkets: susteinability at the consuption junction.' In Pretty, J. (ed). Sage Handbook: Introduction to Environment and Society, pp 411- 428. London: Sage Publications.

Pétonnet, C. (1987) 'L'anonymat ou la pellicule protectrice. Le temps de la réflexion VIII (La ville inquiète)'. Available at: http:/halshs.archives-ouvertes. 
fr/docs/00/11/72/87/PDF/Petonnet_1987_Villeinquiete_V2.pdf. (Consulted 18 January, 2011).

Rennò, R. (2006). Do mármore ao vidro: mercados públicos e supermercados, curva e reta sobre a cidade. São Paulo: Annablume.

Rochefort, R. (2007) Le Bon Consommateur et le Mauvais Citoyen. Paris: Odile Jacob.

Shove, E. (2003) Comfort, cleanliness and convenience: the social organization of normality. New York: Berg.

Velho, G. (1980). O desafio da cidade: novas perspectivas da antropologia brasileira. Rio de Janeiro: Editora Campus.

Warde, A. (2005) 'Consumption and theories of practice'. Journal of Consumer Culture, 5(2):131-153. 
